\title{
The Impact of the Internal Expenditures on R\&D in the Growth of Small and Medium-Sized Businesses in the Republic of Kazakhstan
}

\author{
Rakhilya U. Rakhmetova ${ }^{1}$, Aigul A. Nurpeissova ${ }^{2 *}$, Regina E. Andekina ${ }^{1}$ \\ ${ }^{1}$ «Turan-Astana» University, Str. Ykylas Dukenuly, 29, 010000, Nur-Sultan, Kazakhstan \\ ${ }^{2}$ Narxoz University, Str. Zhandosova 55, 050000, Almaty, Kazakhstan
}

\begin{abstract}
The aim of the article is to investigate the relationship between the number of active small and medium-sized businesses in Kazakhstan and the number of internal costs for research and development projects based on the use of economic and mathematical forecasting methods. As a result of the application of statistical and mathematical methods, the analysis of changes in the number of active SMEs and the volume of R\&D expenditures in the Republic of Kazakhstan for the period 1999-2019 was carried out on the basis of constructing a paired linear regression model. The quality of the model was assessed, the interval for the lower and upper boundaries of the forecast of changes in the indicators of the number of active SMEs from the volume of R\&D expenditures was calculated. An economic interpretation of the calculated data obtained because of constructing a linear paired regression model is given. It was revealed that the number of active SMEs by $94.5 \%$ is explained by the volume of internal R\&D expenditures. A point forecast for the number of active SMEs has been calculated when the volume of internal R\&D expenditures changes for 2022. The calculation of indicators of the lower and upper boundaries of the predicted value of the number of active SMEs has been carried out. With an increase in the volume of internal expenditures on R\&D in the GDP of the Republic of Kazakhstan to 92,178 million tenge, the number of active small and medium-sized enterprises will be in the range from $1,244,436$ to $1,669,622$ units.
\end{abstract}

Keywords: small and medium business; active enterprises; triple helix model; innovation activity; R\&D; number of active enterprises; paired linear regression model; point forecast; interval forecast.

For citation: Rakhmetova, R.U., Nurpeissova, A.A. \& Andekina, R.E. (2021). The impact of the Internal Expenditures on R\&D in the Growth of Small and Medium-Sized Businesses in the Republic of Kazakhstan. Economics: the Strategy and Practice, 16(3), 68-80, https://doi.org/10.51176/1997-9967-2021-3-68-80

* Corresponding author: Aigul A. Nurpeissova - Candidate of Economic Sciences, Associate Professor of the SED Management and Marketing, Narxoz University, Str. Zhandosova 55, 050000, Almaty, Kazakhstan, +77775772298, e-mail: nur_aigul@mail.ru, aigulnurpeissova050979@gmail.com

Conflict of interests: the authors declare that there is no conflict of interest

Financial support: This article has been prepared within the frame of the research project AP08052656 «Readiness assessment of Kazakhstani higher education institutions for transformation within the context of «Triple Helix» funded by the Ministry of Education and Science of the Republic of Kazakhstan.

The article received: 16.04 .2021

The article approved for publication: 01.06. 2021

Date of publication: 30.09.2021 


\title{
ҒЗТК Ж-ға арналған ішкі шығындар көлемінің Қазақстан Республикасындағы шағын және орта бизнестің дамуына ықпалы
}

\author{
Рахметова Р.У. ${ }^{1}$, Нурпеисова А.А..$^{*}$, Андекина Р.Э. ${ }^{1}$ \\ ${ }^{1}$ «Тұран-Астана» университеті,, Ықылас Дукенұльь қ,, 29, 010000, , Нур-Султан, Қазақұстан \\ ${ }^{2}$ Нархоз университеті, Жандосов к, 55, 050000, Алматы, Қазақстан
}

Түйін

\begin{abstract}
Мақалада болжамдаудың экономикалық-математикалық әдістерін қолдану негізінде Қазақстандағы шағын және орта бизнестің белсенді кәсіпорындарының саны мен ҒЗТКЖ- ға ішкі шығындардың саны арасындағы өзара байланысты зерттеу мақсаты қойылған. Статистикалық және математикалық әдістерді қолдану нәтижесінде және жұптық сызықтық регрессиялық моделін құру негізінде Қазақстан Республикасының 1999-2019 жылдар кезеңінде шағын және орта кәсіпорындарының белсенді субъектілер санының және ҒЗТКЖ арналған шығындар көлемінің өзгеруіне талдау жасалды. Модельдің сапасын бағалау жүргізілді, ҒЗТКЖ арналған шығындар көлемінен ШОБ белсенді субъектілер санының көрсеткіштерінің өзгеру болжамының төменгі және жоғарғы шекараларының интервалы есептелінді. Жұптық сызықтық регрессиялық моделін құру нәтижесінде алынған есептік мәліметтердің экономикалық интерпретациясы келтірілді. 2022 жылға арналған ҒЗТКЖ-ға ішкі шығындар көлемінің өзгеруі кезінде ШОБ белсенді кәсіпорындары санының нақты болжамы есептелді. ШОБ белсенді кәсіпорындары санының болжамды мәнінің төменгі және жоғарғы шекараларының көрсеткіштерін есептеу жүргізілді. ҚР ЖІӨ-де ҒЗТКЖ-ға ішкі шығындар көлемі 92178 млн теңгеге дейін ұлғайған кезде белсенді шағын және орта кәсіпорындар саны 1244436-дан 1669622 бірлікке дейін болады.

Түйін сөздер: шағын және орта бизнес, белсенді кәсіпорындар, спиральдың үштік моделі, инновациялық қызмет, ҒЗТКЖ, белсенді кәсіпорындар саны, сызықтық регрессияның жұпталған моделі, нүктелік болжам, аралық болжам.
\end{abstract}

Дәйексөз алу үшін: Рахметова Р.У., Нурпеисова А.А., Андекина Р.Э. (2021). ҒЗТК Ж-ға арналған ішкі шығындар көлемінің Қазақстан Республикасындағы шағын және орта бизнестің дамуына ықпалы. ЭЭкономика: стратегия және практика, 16(3),68-80, https://doi.org/10.51176/1997-9967-2021-3-68-80

* Хат-хабаршы авторы: Нурпеисова А.А. - э.ғ.к., «Менеджмент және маркетинг» БҒД қауымдасқан профессоры, Нархоз университеті, Жандосов қ, 55, 050000, Алматы Алматы, Қазақстан, +77775772298, e-mail: nur aigul@mail.ru, aigulnurpeissova050979@,gmail.com

Мүдделер қақтығысы: авторлар мүдделер қақтығысының жоқтығын мәлімдейді.

Қаржыландыру. Берілген зерттеу жұмысы ҚР БжҒМ қаржыландыратын, ЖТН - АР08052656 «Қазақстандық жоғары оқу орындарының «Үштік спираль» тұрғысында трансформацияға дайындығын бағалау» атты ғылыми жобаның шеңберінде дайындалған.

Мақала редакцияға түсті: 16.04 .2021

Жариялау туралы шешім қабылданды: 01.06.2021

Жарияланды: 30.09.2021 


\title{
Влияние объема внутренних затрат на НИОКР на развитие малого и среднего бизнеса Республики Казахстан
}

\author{
Рахметова P.У. ${ }^{1}$, Нурпеисова А.А. ${ }^{2 *}$, Андекина P.Э. ${ }^{1}$ \\ ${ }^{\prime}$ Университет "Туран-Астана», ул. 29, 010000, Нур-Султан, Казахстан \\ ${ }^{2}$ Университет Нархоз, ул. Жандосова, 55, 050000, Алматы, Казахстан
}

\begin{abstract}
Аннотация
В статье поставлена цель - исследовать взаимосвязь между количеством активных предприятий малого и среднего бизнеса (МСБ) в Казахстане и количеством внутренних затрат на научно-исследовательских и опытноконструкторских разработок на основе применения экономико-математических методов прогнозирования. В результате применения статистико-математических методов проведен анализ изменения количества активных субъектов МСП и объемов затрат на НИОКР в Республики Казахстан за период 1999-2019 годы на основе построения модели парной линейной регрессии. Произведена оценка качества модели, рассчитан интервал для нижней и верхней границ прогноза изменения показателей количества активных предприятий МСБ от объемов затрат на НИОКР. Дана экономическая интерпретация полученных в результате построения модели линейной парной регрессии расчетных данных. Выявлено, что количество активных предприятий МСБ на 94,5\% объясняется объемом внутренних затрат на НИОКР. Рассчитан точечный прогноз количества активных предприятий МСБ при изменении объемов внутренних затрат на НИОКР на 2022 год. Проведен расчет показателей нижних и верхних границ прогнозного значения количества активных предприятий МСБ. При увеличении объемов внутренних затрат на НИОКР в ВВП РК до 92178 млн тенге количество активных малых и средних предприятий будет в пределах от 1244436 до 1669622 единиц.
\end{abstract}

Ключевые слова: малый и средний бизнес, активные предприятия, модель тройной спирали, инновационная активность, НИОКР, количество активных предприятий, модель парной линейной регрессии, точечный прогноз, интервальный прогноз.

Для цитирования: Рахметова Р.У., Нурпеисова А.А., Андекина Р.Э. (2021). Влияние объема внутренних затрат на НИОКР на развитие малого и среднего бизнеса Республики Казахстан. Экономика: стратегия и практика, 16(3), 68-80, https://doi.org/10.51176/1997-9967-2021-3-68-80

* Корреспондирующий автор: Нурпеисова Айгуль - к.э.Н., ассоциированный профессор НОД «Менеджмент и маркетинг» университета Нархоз, ул. Жандосова, 55, 050000, Алматы, Казахстан, +87475933491, e-mail: nur_aigul@mail.ru, aigulnurpeissova050979@gmail.com

Конфликт интересов: авторы заявляют об отсутствии конфликта интересов.

Финансирование. Это исследование выполнено в рамках проекта «Оценка готовности казахстанских высших учебных заведений к трансформации в контексте «Тройная спираль», финансируемого МОН РК, ИРН - AP08052656.

Статья поступила в редакцию: 16.04 .2021

Принято решение о публикации: 01.06 .2021

Опубликовано: 30.09 .2021 


\section{Introduction}

Entrepreneurship is one of the key components of an innovation-driven economy. The level of development, the nature, and scale of entrepreneurial activity affects the rate of economic growth, the structure, and quality of the gross national product, solve the problem of employment, and many other socially significant tasks of the state $[1,2]$.

According to official statistics, the gross value added of small and medium-sized businesses in the Republic of Kazakhstan at the end of 2019 amounted to 22029151.33 million tenges, and its share in the republic's GDP reached $31.7 \%$. The number of active small and medium-sized businesses is growing annually, so in 2019 their number was 1327742 . As of January 2020, there are 1325615 operating small and medium-sized businesses. The leaders in the development of SMEs are the cities of Almaty - 191 thousand and Nur-Sultan - 134 thousand, Almaty and Turkestan regions [3].

In turn, the main indicators affecting the growth of the number of business entities and the development of the most important driver of the innovative economy as small and mediumsized businesses are factors of the institutional environment, indicators of public and private funding of science, the number of universities, entrepreneurial type, material and technical equipment of enterprises, the level infrastructure support, the level of regional development of the country, demographic and many other factors.

It is important to note that in the Republic of Kazakhstan, the development of small and medium-sized enterprises (SMEs) has been taken under control at the highest level since the very beginning of building a market-oriented economy of post-Soviet development. The comprehensive approach of the state policy for the development of SMEs in the Republic of Kazakhstan includes, first of all, the implementation of strategic guidelines formulated in state strategies and programs: Strategy "Kazakhstan-2050”, "Business Roadmap-2025" and others.

The Damu Entrepreneurship Development Fund JSC was created as the main financial operator of measures of state support for SMEs, financing business projects of entrepreneurs of Kazakhstan. So, at the end of 2019, more than 24 thousand projects were supported for a total loan amount of more than 600 billion tenges.

However, despite all the measures taken to promote SMEs, Kazakhstan is characterized by an insufficient realization of the potential of the Kazakhstani small and medium-sized business sector in employing the population, creating a competitive environment, and establishing and developing an innovative economy.

It is in the context of the triple helix model that science-intensive innovative small and medium-sized businesses depend on the capabilities of universities and organizations to carry out fundamental and applied research and conduct research and development [4]. The research functions of universities on the example of the developed countries of Europe, the United States have proved their effectiveness in the formation of competitive, innovative small and medium-sized businesses. The combined efforts of all three components of the "universities-statebusiness" triple helix model will contribute to the development of the economy of Kazakhstan according to the scenario of an innovative direction since it is in this combination that the effect of emergence or synergy of the potentials of all three institutional spheres arises.

Therefore, the problem of studying small and medium-sized businesses is of particular importance from the point of view of the influence on their development of factors arising from the constructive interaction of state and regional authorities with representatives of the scientific and educational sector, universities, research institutes, and the business structures themselves. Of particular interest is the use of economic and statistical methods for conducting various kinds of research, using methods of correlation- regression analysis, modeling, and forecasting.

We emphasize that the significance of studies of the influence of factors on the main indicators of SME development using methods of economic and statistical analysis is certainly high from a scientific and practical point of view, precisely to obtain analytically and forecast information for the development of scientific and practical proposals to support this sector.

As we noted, the level of development of small and medium-sized businesses in the country as a whole is influenced by many socioeconomic factors. Factors of its financial support and incentives play an important role in supporting the development of competitive entrepreneurship. The importance of financing education, science, start-ups for enhancing the innovative growth of business entities, the development of innovative infrastructure in the context of the triple helix model is undoubtedly great.

One of the urgent problems of SME development, in particular, increasing the number of active enterprises in Kazakhstan, is considered the task of sufficient allocation of funds for research and development (R\&D) in terms of accumulating the innovative potential of entrepreneurial structures and subjects of the republic. 


\section{Literature review}

A review of the available research in this area has shown that research scientists from all over the world have directed their minds and minds on a variety of aspects of this rather broad and complex topic.

For example, one can single out a separate group of developments aimed at studying the development of small and medium-sized businesses in the system of interaction between the state, business, and universities, taking into account regional and territorial characteristics. In particular, in a study by Thai scientists Pankom Sriboonlue, Suteera Puangpronpitag [5], recommendations were developed to support regional small and medium-sized enterprises in Thailand to move to innovative entrepreneurship within the framework of the Thailand 4.0 national development model. According to the authors, small firms must increase their creativity and innovation to create valueadded products.

Another study by Suteera Puangpronpitag [6], explores in more detail the role of regional universities interacting with their regions to realize a knowledge-based economy, as compared to Thai and British universities. The work will be of particular interest since it reflects the results of a comparative analysis of the development of SMEs and regions in the context of the triple helix model using the examples of universities in Thailand and Great Britain, that is, a developed and developing economic systems.

The results of the analysis of the potential for interaction of all three elements of the triple helix model (academic sector, local business, and local government) with the development of recommendations for developing a cooperation model for the development of SMEs in Indonesia are presented in the article by scientists Lenny Martini, Jann Hidajat Tjakraatmadja, Yudo Anggoro, Adita Pritasari, Libertha Hutapea [7].

Oskar Villarreal, Nuria Calvo in their study [8] using the example of the Dominican Republic considered the possibilities of international cooperation in the field of innovation and proposed a new model - the model of global open innovation - as an alternative approach to the transfer of innovations.

An interesting approach of the authors of the article Towards "meta-innovation" in Brazil: The evolution of the incubator and the emergence of a triple helix [9] Henry Etzkowitz, José Manoel Carvalho de Mello, Mariza Almeida, in which attention is paid to the regional development of the triple spirals in Brazil through a strategy of incubating top-down, bottom-up and horizontal meta-innovations.

Qivind Strand, Loet Leydesdorff investigated the aspect of the development of a triple helix between technologies, firms, and geography based on the study of the specifics of the territorial development of Norway [10]. In particular, they pointed out that the interaction of universities and businesses promote the innovative activity of entrepreneurs.

Using economic and statistical methods on the example of Mexican enterprises, the authors Maribel Guerrero, David Urbano investigated the influence of agents of the triple helix on the efficiency of entrepreneurial innovation [11]. In particular, they analyzed the impact of small and medium-sized enterprises' links with other enterprises, universities, and the state on their innovation activities (access to knowledge/ technology, funding sources, government subsidies), as well as the deterrent effects that arise from this. The authors, in their conclusions, provide recommendations for the main participants in the Mexican system of science, technology, and innovation for the development of entrepreneurial innovation in Mexico.

In addition to the regional aspect of the development of SMEs in the context of the triple helix model, another group of scientific research can be distinguished, which reflects other specifics of the problems we are studying.

For example, scientists are deeply studying the possibilities of cluster innovative development of small and medium-sized enterprises based on the concept of a triple helix [12].

There are publications on the development of cooperation between the state, universities, and business structures for the development of the energy industry, light industry, etc., there are also approaches to studying the possibilities of using web mining to determine the impact of the Triple Helix on the growth of small and medium-sized firms $[13,14]$.

A brief review of the world experience in the development of a competitive and innovative type of small and medium-sized businesses showed that an important condition for this is the state and development of science in the country. It is crucial to study the relationship between the number of active enterprises in the category of small and medium-sized businesses and internal expenditures on R\&D in the Republic of Kazakhstan in the context of the triple helix model.

In this regard, we have set a goal - to investigate the relationship between the number of active small and medium-sized enterprises (SMEs) in Kazakhstan and the number of internal costs for research and development projects based on the use of economic and mathematical forecasting methods.

Besides, it should be noted that in Kazakhstan this kind of research has not yet been carried out, the nature of this relationship has not been analyzed 
by statistical methods, in particular, the coefficient has not been calculated.

\section{Methodology}

The study of the relationship between the main indicator characterizing the state of SME development in the country, namely, the number of active enterprises and the volume of internal expenditures on R\&D as one of the most important indicators of the state and development of science was chosen as the object of analytics not by chance, since in the triple helix model it is a particular round of intertwining science and the state is essential for the support and prosperity of business.

As analyzing indicators, we took the number of active small and medium-sized businesses in the Republic of Kazakhstan and the volume of internal costs for R\&D for the period from 1999 to 2019, available in the sources of official statistics, Table 1.

Table 1 - Initial data for building a paired linear regression model

\begin{tabular}{|c|c|c|}
\hline \multirow{3}{*}{ Period } & \multicolumn{2}{|c|}{ Indicators } \\
\hline & 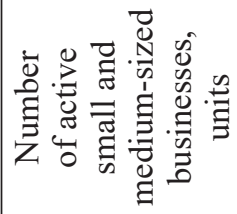 & 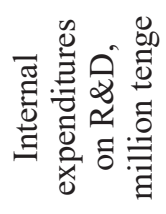 \\
\hline & Y & $X$ \\
\hline 1999 & 30172 & 3500,50 \\
\hline 2000 & 110151 & 4706,80 \\
\hline 2001 & 254088 & 7154,10 \\
\hline 2002 & 323731 & 9632,90 \\
\hline 2003 & 383032 & 11643,50 \\
\hline 2004 & 447038 & 14579,80 \\
\hline 2005 & 504824 & 21527,40 \\
\hline 2006 & 570060 & 24799,90 \\
\hline 2007 & 640900 & 26835,50 \\
\hline 2008 & 703802 & 34761,60 \\
\hline 2009 & 659214 & 38988,70 \\
\hline 2010 & 652886 & 33466,80 \\
\hline 2011 & 837083 & 43351,60 \\
\hline 2012 & 801362 & 51253,10 \\
\hline 2013 & 879921 & 61672,70 \\
\hline 2014 & 922285 & 66347,60 \\
\hline 2015 & 1239682 & 69302,90 \\
\hline 2016 & 1103642 & 66600,10 \\
\hline 2017 & 1143376 & 68884,20 \\
\hline 2018 & 1238708 & 72224,60 \\
\hline 2019 & 1327742 & 82333,10 \\
\hline
\end{tabular}

Note - compiled by the authors from the data [15].
As can be seen from the data in Table 1, in Kazakhstan for the period from 1999 to 2019. there was an increase in the number of active SMEs from 30,172 to $1,327,742$ units, the growth rate was 44.0. In turn, an increase was also recorded in internal $R \& D$ expenditures over the years. If in 1999 the volume of internal expenditures on R\&D amounted to 3500.50 million tenges, then in 2019 the indicator increased by more than 23.5 times and amounted to 82333.1 million tenges.

Comparison of trends of the analyzed indicators for the period from 1999 to 2019 has been presented in Figure 1 that shows a positive upward trend in the metrics included in the paired linear regression model.

\section{Number of active SMEs, $(\mathrm{Y})$}

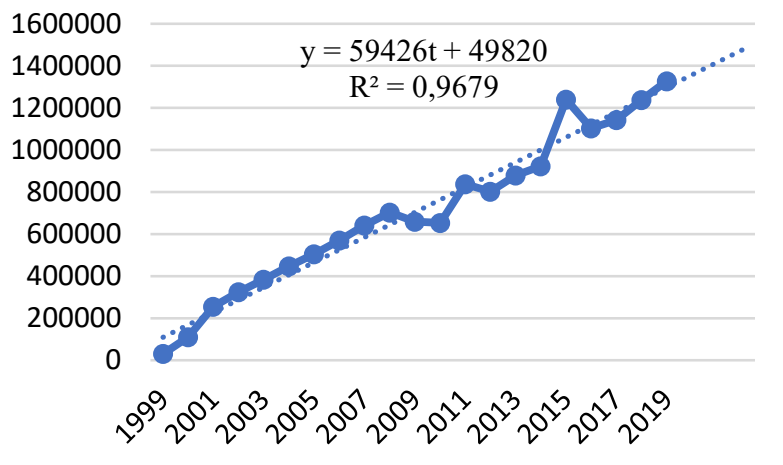

Internal expenditures on $\mathrm{R} \& \mathrm{D},(\mathrm{X})$

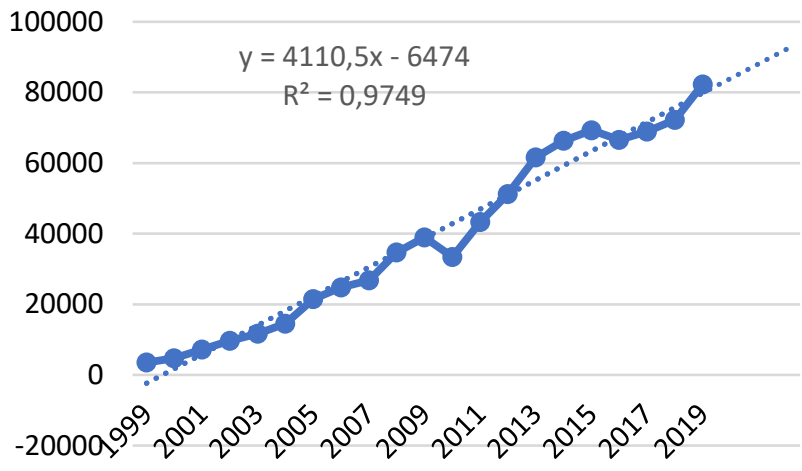

Figure 1 - Dynamics of growth of the analyzed indicators for 1999-2019.

Note - compiled by the authors according to table 1 .

The graphs of the initial data show that there is a linear relationship between the analyzed indicators, therefore it is necessary to determine the closeness and nature of this relationship.

As the results of the analysis of the world experience of state support for innovative small and medium-sized enterprises in the USA, Japan, 
India, China, Russia have shown, it is financing in combination with effective management, technical consulting that contributes to the development and commercialization of promising innovative projects and science-intensive developments [16, $17]$.

In general, for the transition to a knowledge economy, many countries have taken a course towards promoting R\&D activity of small and medium-sized businesses as the most important foundation for innovative development. Therefore, domestic scientists are also puzzled by the questions of how the state financing education and science, supporting R\&D, contributes to the increase of science intensity and innovation of small and medium-sized businesses in our country. It is necessary from a practical point of view to substantiate the ways, priorities, directions, and mechanisms for improving the interaction of the state together with private business units and the university sector, the development of small and medium-sized businesses in Kazakhstan. In this regard, we believe that the use of economic and statistical methods in the study of the problems of SME development in the context of symbiosis and triple interaction of the state-science-business, in particular, the application of the method of constructing a paired linear regression model for constructing predictive options for increasing the number of active small and medium-sized enterprises in the country in the context of changes in the volume of internal expenditures on R\&D for the implementation of the strategic task - the development of SMEs in the Republic of Kazakhstan.

For this reason, in this study, we decided to identify the mutual influence of two main indicators: the number of active SMEs and the amount of R\&D costs in the Republic of Kazakhstan based on the construction of a paired linear regression model and calculate point and interval forecasts for the variation of the analyzed indicators. In carrying out the research, we relied on the methodological material of a textbook on econometrics [18].

The methodology of our research included several stages using various scientific and analytical methods, Figure 2.

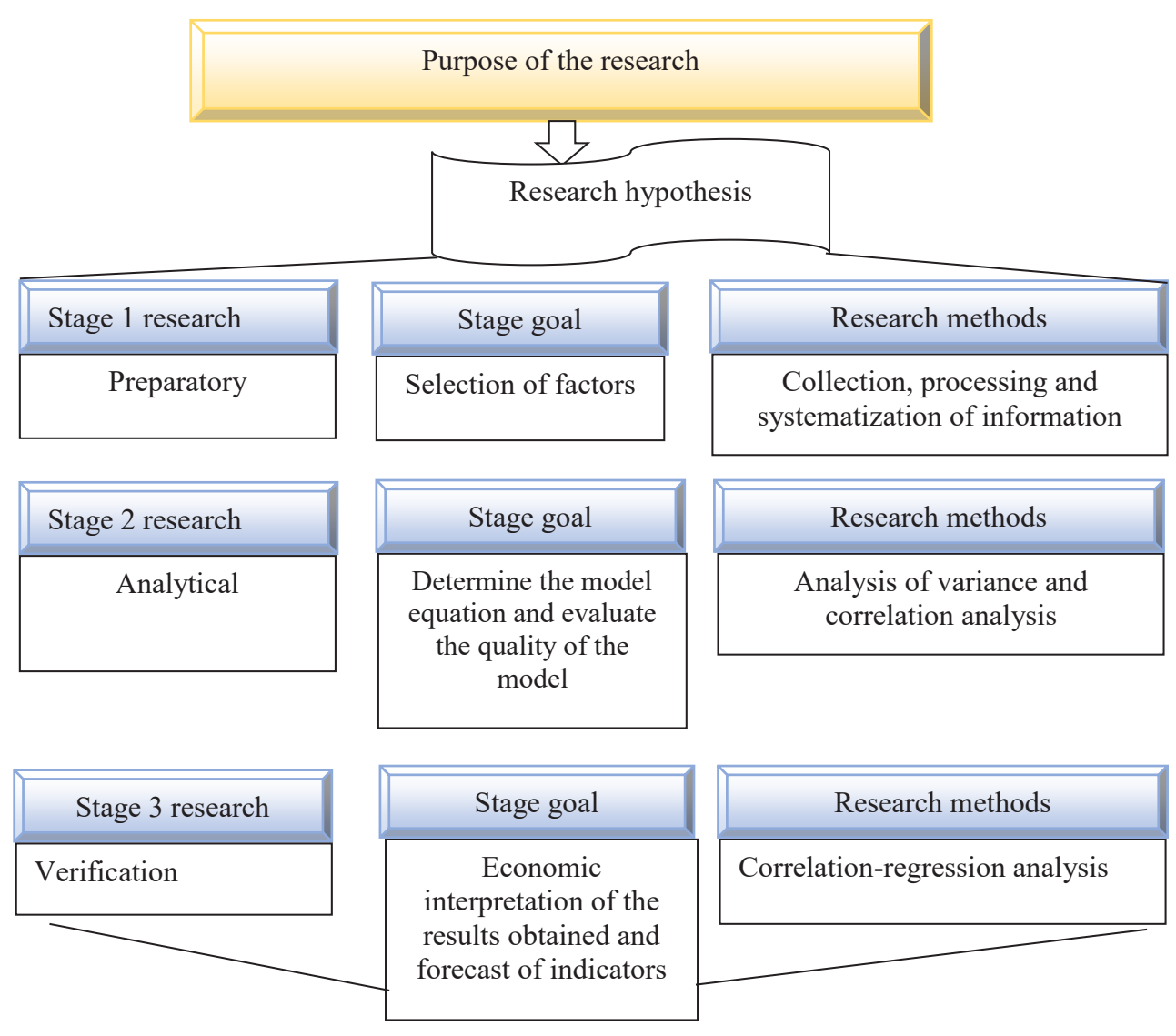

Figure 2 - Research methodology

Note - compiled by the authors. 
1. The preparatory stage consisted of identifying factors influencing the number of active enterprises among SMEs in Kazakhstan and choosing a specific factor for conducting linear pairwise regression. It used the method of systematizing scientific research on the problems of supporting and developing small and mediumsized businesses, as well as the method of collecting and processing official statistical data.

2 . The analytical stage consisted of plotting a correlation field or a scatter diagram to detect the presence of homoscedasticity or the condition of homoscedasticity of the dispersion of the linear regression model. Having built a trend line, we obtained a regression model describing the relationship between the number of active SMEs and the volume of internal R\&D costs.

To check the quality of the model we obtained, we assessed the significance of the regression coefficients using the Student's t-test, and also applied the test method using analysis of variance and correlation.
3. Verification stage. After analyzing the quality of the constructed model and statistic significance of the regression coefficients, we gave an economic interpretation of the results of the study, and also using economic and statistical methods, we constructed chiseled and interval forecasts of changes in the number of active SMEs from bringing the volume of $R \& D$ expenditures to $1 \%$ in the GDP of the Republic of Kazakhstan.

To confirm the accuracy of the forecast, we carried out several calculations, in particular, for this we found the relative value of the differences between the upper and lower boundaries - the indicator $\mathrm{D}$, using the method of constructing the confidence interval.

Results and discussion. To study the strength and nature of the impact of the volume of internal expenditures on $\mathrm{R} \& \mathrm{D}$ (dependent variable $\mathrm{X}$ ) on the number of active SMEs (resulting in variable $\mathrm{Y}$ ) in the Republic of Kazakhstan, a linear pairwise regression model was built based on the data in Table 1.

Initially, a correlation field plot or scatter plot was built, according to Figure 3 .

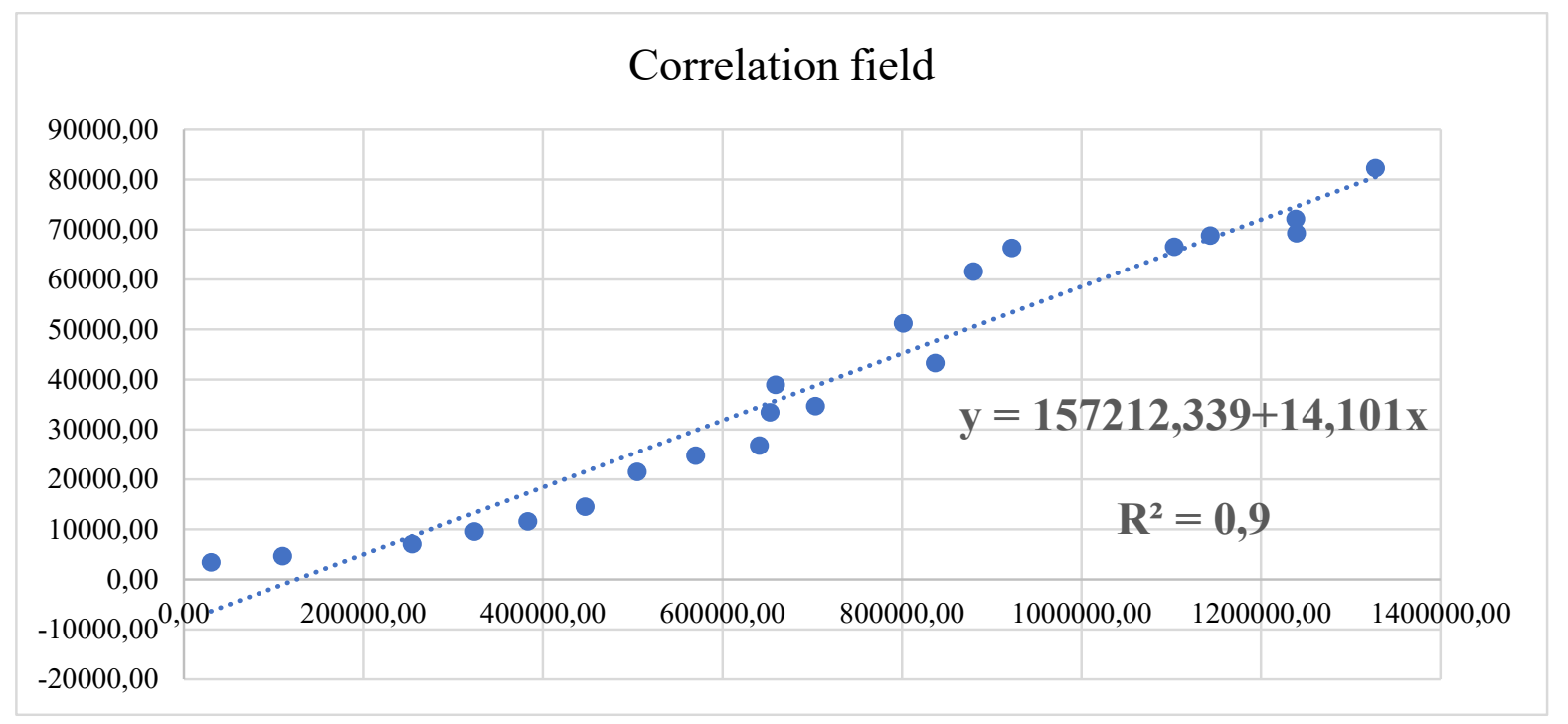

Figure 3 - Graph of the correlation field and the regression line of the original data

Note - compiled by the authors.

As can be seen from the graph, the analyzed data formed an elongated «cloud», that is, this allowed us to say about the presence of homoscedasticity of the observation or the condition of homoscedasticity of the variance of the linear pairwise regression model. Using the function of adding a linear trend in Excel, we derived the regression equation and the coefficient of determination r-squared.
So, the regression equation describing the relationship between the volume of internal R\&D costs and the number of active SMEs in the Republic of Kazakhstan is as follows:

$$
\mathrm{Y}=157212,339+14,101 \cdot \mathrm{X}
$$


The analysis of the indicators of the regression statistics, reflected in Table 2, allowed us to make an intermediate conclusion that the relationship between the indicators exists and it is strong and direct.

To assess the quality of the built model, we found out the significance of the regression coefficient using the Student's t-test, which was 2.093 with a probability of $5 \%$ error.

Further, putting forward 2 alternative hypotheses for the coefficients a and $b$ :

1 hypothesis - H0_a: a $=0$, that the coefficient $\mathrm{a}$ is statistically insignificant.

2 hypothesis - H1_a: $a \neq 0$, that the coefficient $\mathrm{a}$ is statistically significant.

and to test the significance of the coefficient $b$ the following 2 hypotheses:

1 hypothesis - H0_b: $b=0$, that the coefficient $\mathrm{b}$ is not statistically significant.

2 hypothesis - H1_b: $b \neq 0$, that the coefficient $\mathrm{b}$ is statistically significant.

we found that both coefficients are statistically significant, this follows from comparing the t-statistic with the t-critical, which showed the following results:

t-statistics of the coefficient $\mathrm{a}=4.339$, which is more than 2.101

t-statistic of coefficient $b=17.99$, which is more than 2.101

Thus, with a probability of $95 \%$, the hypotheses $\mathrm{HO}$ a and $\mathrm{HO}$ b are rejected and both coefficients (the number of active SMEs and the volume of internal $R \& D$ costs) are significant.

The confidence interval analysis method also confirmed the conclusion that both coefficients are statistically significant for constructing paired linear regression. Thus, the data of analysis of variance in Table 2 showed that both analyzed coefficients are not included in the confidence interval of the upper and lower boundaries with both a probability of $95 \%$ and a probability of $99 \%$.

Also, if we look at the P-value data for both coefficients in Table 2, we see that they are less than the standard error (less than 0.5).

Thus, the analysis of the quality of the model in three ways: by the significance of the regression coefficient using the Student's t-test, by the analysis of the confidence interval, by the analysis of $\mathrm{P}$-values made it possible to establish the statistical significance of both analyzed coefficients for the paired linear regression model.

Further, for the analysis of variance regression, we hypothesized that there is a linear functional relationship between $\mathrm{x}$ and $\mathrm{y}$, that is, between the variables the number of active SMEs and the volume of internal R\&D costs: $H 0: b=0$
In our case, a comparison of the observed value of Fisher's f-criterion with the f-critical showed that there is a linear relationship between the two variables $\mathrm{x}$ and $\mathrm{y}$, since $323.559>4.381$ $\Rightarrow \mathrm{H} 0: \mathrm{b}=0$ deviates. Comparing the t-observed 17.99 and the t-critical 2.093, we determined that $b$ parameter is statistically significant.

To determine the strength of this relationship, further, using the data of regression statistics (Table 2 ), we found out that the correlation coefficient or multiple $\mathrm{R}=0.972$, it is higher than 0.44 , that is, we conclude that the correlation coefficient is significant with a probability of $95 \%$ and the hypothesis H0_r: $r=0$ is rejected, the relationship between the number of active SMEs and the volume of internal R\&D spending is strong and direct.

The analysis of the value of the coefficient of determination of the R-squared allowed us to give the following economic interpretation: the variation of the variable $y$, namely the number of active SMEs by $94.5 \%$, is explained by the variation of the variable $\mathrm{x}$ - that is, the volume of internal R\&D costs.

Other factors not taken into account in the model, but certainly also affect the number of active small and medium-sized enterprises in Kazakhstan, accounting for about $5.5 \%$. For example, the level of technical equipment, the number of loans issued, the level of infrastructure development, the availability of the Internet, etc.

The calculation of the key quality indicator as the average approximation error showed that it was $4.87 \%$, that is, the quality of the model fit is high since it should be no higher than 7\%.

Thus, the regression equation allows making the following economic interpretation.

If the coefficient $x$, namely the volume of internal expenditures on R\&D in Kazakhstan, increases by 1 billion tenges, then the variable $\mathrm{y}$ the number of active SMEs will increase by 14101 units.

Analysis of the studies available in the literature on the development of small and medium-sized businesses, increasing its innovative activity, in particular the works of domestic and foreign scientists, specialists showed that the share of domestic expenditures on $R \& D$ in the GDP of countries with high indicators of development of small and medium-sized innovative entrepreneurship is about 2.5-3.0\%. In Kazakhstan, for comparison, the share of domestic R\&D expenditures in GDP at the end of 2019. is only $0.12 \%$, on average for the period from 1999 to 2019 . the indicator is $0.19 \%$. 


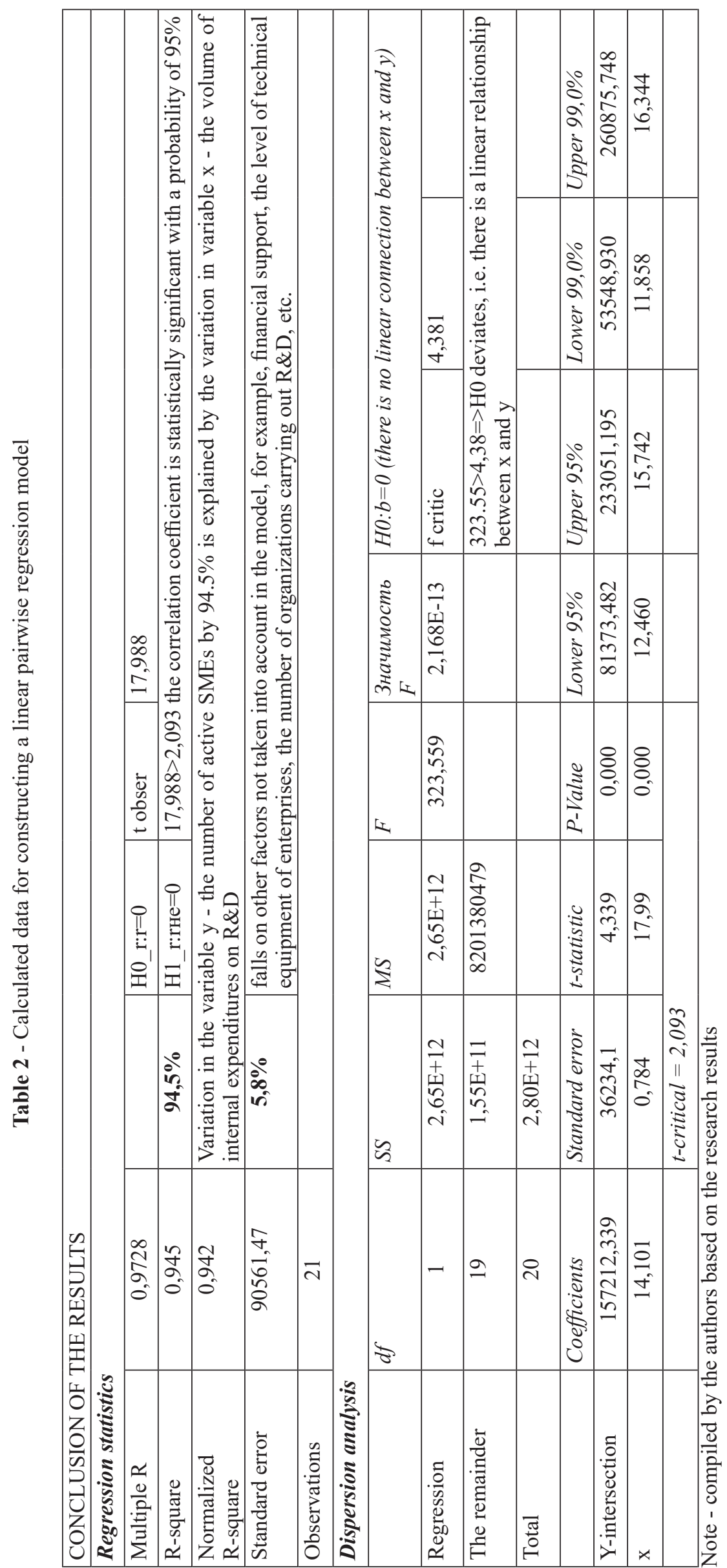


For a point forecast, we calculated the $X p$ indicator (the volume of internal costs for R\&D), used the trend equation (Figure 1), based on the current tendency for the period studied from 19992019 , where $\mathrm{t} t=1,2, \ldots .21$ time periods, from there for 2022 year $\mathrm{t}=24$, then we will have:

$$
\mathrm{X}(2022)=4110,5 * \mathrm{t}-6474=92178 \mathrm{mln} \text { tenge, }
$$

Inserting the meanings into equation (1) we will have the point meaning

$\mathrm{Y}(2022 \Gamma)=157212,34+14,1 * 92178=1457029$ units,

In comparison with 2019 the volume of internal expenditures on $R \& D$ will increase by $12 \%$, and the number of active SMEs by $10 \%$.

Next, the standard error of the forecast and the boundaries of the corresponding confidence interval were calculated using the formulas [23]:

Forecast standard error formula:

$$
m_{\hat{y}_{p}}=\sigma_{o c m} \cdot \sqrt{1+\frac{1}{n}+\frac{\left(x_{p}-\bar{x}\right)^{2}}{\sum(x-\bar{x})^{2}}}
$$

and the forecast confidence interval

$\mathrm{Y}=\mathrm{Y} * \pm \operatorname{tcr}$ my (3)

where $\mathrm{Y}^{*}$ is the point predicted value of $\mathrm{Y}$.

The calculated standard error according to the formula (2) $\mathrm{m}_{\mathrm{y}}=101718.9$, then

$$
\mathrm{Y}=1457029 \pm 2.09 * 101718.9 .
$$

Using this expression

$$
\mathrm{Y}_{\text {lower }}=1457029-2.09 * 101718.9=1244436 \text {, }
$$
1669622 ,

and $\mathrm{Y}_{\text {upper }}=1457029+2.09 * 101718.9=$

hence the point value of $\mathrm{Y}$ is in the intervals [1244436; 1669622] or $1669622<1457029$ $<1669622$.

So, we received data on the lower and upper boundaries for plotting the intervals of the predicted value $y$ and made the following conclusion: with a probability of $95 \%$, in case of increasing the volume of internal R\&D expenditures in the GDP of the Republic of Kazakhstan to 92,178 million tenge, the number of active small and mediumsized enterprises will be in the range from 1244436 to 1669622 units.

\section{Conclusion}

Thus, according to the results of the study, the following conclusions can be drawn.

Firstly, small and medium-sized businesses in the Republic of Kazakhstan, due to objective, historical, structural, and regional reasons, have not yet become a generating factor in an innovationoriented economy, although the importance of its role in the formation of the knowledge economy, innovation, digitalization is recognized and the state is taking comprehensive legislative measures, institutional, fiscal, economic nature. However, the efforts of one state are not sufficient. We need the most effective interaction of both science and business itself so that in the aggregate the integration of all three elements of the triple helix model would give the very desired effect of "substitution of functions" when the spheres of interests of these structures are intertwined.

Secondly, the obtained model of paired linear regression, which describes the dependence of indicators of the number of active SMEs with an increase in $\mathrm{R} \& \mathrm{D}$ costs, is adequate and statistically significant. In this regard, to develop strategies for financing R\&D of SMEs in the republic, we believe that the results of point and interval forecasts of an increase in the number of active SMEs in the context of changes in $R \& D$ costs will have a practical use, and will also serve as a basis for further scientific research in this area.

Thirdly, the study of the development of SMEs from the standpoint of the application of economic and statistical methods has enormous potential and a wide field for researchers. Many factors need to be taken into account that affects the performance of SMEs, which in turn require careful selection and justification. In the process of a preliminary analysis of the causal relationship between indicators of the development of small and medium-sized enterprises and factors in the form of the number of R\&D employees, the number of universities, the number of loans issued by STBs for SMEs and others, the complex nature of mutual influence and possible distortion of the results of analysis and forecasting has been revealed. The results of the analysis made it possible to determine the type, degree of dependence of the variables, and the development of point and interval forecasts can serve as the basis for developing recommendations for increasing $\mathrm{R} \& \mathrm{D}$ costs, contributing to the growth of innovative activity of SMEs in Kazakhstan. 


\section{References}

1. Baytenova, A.T. (2012) Razvitiye malogo i srednego biznesa v Respublike Kazakhstan. Ekonomicheskaya nauka i praktika: materialy I Mezhdunar. nauch. konf., Chita: Izdatelstvo Molodoy uchenyy, 50-53. https://moluch.ru/conf/econ/ archive/14/1648/

2. Alshanskaya, A. Razvitiye malogo i srednego biznesa $\mathrm{v}$ sfere uslug Kazakhstana: sovremennoye sostoyaniye i klyuchevyye problem [Электронный pecypc]. URL: $\quad$ http://kisi.kz/index.php/ru/ publikatsii/54-alshanskaya-anna-alekseevna/4534razvitie-malogo-i-srednego-biznesa-v-sfere-uslugkazakhstana-sovremennoe-sostoyanie-i-klyuchevyeproblemy (data obrashcheniya: 17.02.2021).

3. Kak malyy i sredniy biznes vliyayet na konkurentosposobnost Kazakhstana [Электронный pecypc]. URL: https://strategy2050.kz/ru/ news/kak-malyy-i-sredniy-biznes-vliyaetna-konkurentosposobnost-kazakhstana/(data obrashcheniya: 11.02.2021).

4. Gumargaliev, I. E. Model' «trojnoj spirali» kak stimul povysheniya innovacionnoj aktivnosti vuzov, 383-392. https://cyberleninka.ru/article/n/ model-troynoy-spirali-kak-stimul-povysheniyainnovatsionnoy-aktivnosti-vuzov (data obrashcheniya: 22.02.2021)

5. Sriboonlue, P., Puangpronpitag, S. (2019) Towards Innovative SMEs: An Empirical Study of Regional Small and Medium Enterprises in Thailand. Thailand Procedia Computer Science Volume 158, 819825

6. Puangpronpitag, S. (2019) Triple Helix Model and Knowledge-Based Entrepreneurship in Regional Engagement: A Case Study of Thai and UK Universities. Procedia Computer Science Volume 158, 565-572

7. Martini, L., Tjakraatmadja, J.H., Anggoro, Y., Pritasari, A., Hutapea, L. (2012) Triple Helix Collaboration to Develop Economic Corridors as Knowledge Hub in Indonesia. Procedia - Social and Behavioral Sciences Volume 52, 130-139

8. Villarreal, O., Calvo, N. (2015) From the Triple Helix model to the Global Open Innovation model: A case study based on international cooperation for innovation in Dominican Republic. Journal of Engineering and Technology Management Volume 35, 71-92
9. Etzkowitza, H., Carvalho de Mello, J.M., Almeida, M. (2005) Towards "meta-innovation" in Brazil: The evolution of the incubator and the emergence of a triple helix. Research Policy Volume 34, Issue 4, 411-424

10. Strand, Q., Leydesdorff, L. (2013) Where is synergy indicated in the Norwegian innovation system? Triple-Helix relations among technology, organization, and geography. Technological Forecasting and Social Change Volume 80, Issue 3, 471-484

11. Guerrero, M., Urbano, D. (2017) The impact of Triple Helix agents on entrepreneurial innovations' performance: An inside look at enterprises located in an emerging economy. Technological Forecasting and Social Change Volume 119, 294-309

12. Herlian, S. (2015) Regional Innovation Cluster for Small and Medium Enterprises (SME): A Triple Helix Concept. Procedia - Social and Behavioral Sciences Volume 169, 151-160

13. Visintainer Lerman, L. Gerstlberger, W., Lima, M.F., Frank, G.A. (2021) How governments, universities, and companies contribute to renewable energy development? A municipal innovation policy perspective of the triple helix Energy Research \& Social Science Volume 71, 101854

14. Li, Y., Arora, S., Youtie, J., Shapira, Ph. (2018) Using web mining to explore Triple Helix influences on growth in small and mid-size firms. Technovation Volumes 76-77, 3-14

15. Statistikamalogoi srednego predprinimatelstva. URL: https://stat.gov.kz/official/industry/139/statistic/7

16. Zarubezhnyy opyt gosudarstvennoy podderzhki innovatsionnykh malykh i srednikh predpriyatiy. [Электронный ресурc]. URL: http://www. vneshmarket.ru/content/document r 53C5CE2BF73C-4DE2-9366-31DC6A60F4A8.html (data obrashcheniya: 15.02.2021).

17. Mirovoy opyt podderzhki NIOKR malogo biznesa. [Электронный ресурc]. URL: https://popecon. ru/otrivki/422-mirovoi-opyt-podderzhki-niokr-malogobiznesa.html (data obrashcheniya: 10.03.2021).

18. Rakhmetova, R.U. (2015) Ekonometrika: Uchebnik dlya bakalavrov ekonomicheskikh spetsialnostey. Almaty, Ekonomika 
Rakhila U. Rakhmetova - Doctor of Economic Sciences, Professor of «Turan-Astana» University, Kazakhstan. e-mail: rakhmetova@rambler.ru. ORCID ID https://orcid.org/0000-0001-5869-7224

* Aigul A. Nurpeissova - Candidate of Economic Sciences, Associate Professor of the SED Management and Marketing, Narxoz University, Kazakhstan, e-mail: aigulnurpeissova050979@gmail.com. ORCID ID https://orcid. org/0000-0002-4853-6686

Regina E.Andekina - Ph.D., Associate Professor of «Turan-Astana» University, Kazakhstan, e-mail: andekinaregina@, gmail.com. ORCID ID https://orcid.org/0000-0002-0740-0686

\section{Авторлар туралы мәліметтер}

Рахметова Р.У. - э.ғ.д., профессор «Тұран-Астана» университеті, Қазақстан, e-mail: rakhmetova@rambler.ru. ORCID ID https://orcid.org/0000-0001-5869-7224

* Нурпеисова А.А. - э.ғ.к., «Менеджмент және маркетинг» БҒД қауымдасқан профессоры, Нархоз университеті, Қазақстан, e-mail: aigulnurpeissova050979@gmail.com. ORCID ID https://orcid.org/0000-0002-4853-6686

Андекина P.Э. - PhD, қауымдастырылған профессоры «Тұран-Астана» университеті, Қазақстан, е-таil: andekinaregina@gmail.com. ORCID ID https://orcid.org/0000-0002-0740-0686

\section{Сведения об авторах}

Рахметова Р.У. - д.э.н., профессор университета « Туран-Астана», Казахстан, е-mail: rakhmetova@rambler.ru. ORCID ID https://orcid.org/0000-0001-5869-7224

* Нурпеисова А.А. - к.э.н., ассоциированный профессор НОД «Менеджмент и маркетинг» университета Нархоз, Казахстан, e-mail: aigulnurpeissova050979@gmail.com. ORCID ID https://orcid.org/0000-0002-4853$\underline{6686}$

Андекина P.Э. - PhD, ассоциированный профессор университета «Туран-Астана», Казахстан, е-таil: andekinaregina@gmail.com. ORCID ID https://orcid.org/0000-0002-0740-0686 